\title{
Forum
}

PMLA invites members of the association to submit letters, typed and double-spaced, commenting on articles in previous issues or on matters of general scholarly or critical interest. The editor reserves the right to reject or edit contributions for publication and offers the authors discussed an opportunity to reply to the letters published. The journal discourages footnotes and regrets that it cannot consider any letter of more than 1,000 words.

\section{Virginia Woolf and Madness}

\section{To the Editor:}

Thomas C. Caramagno's essay on Virginia Woolf ("Manic-Depressive Psychosis and Critical Approaches to Virginia Woolf's Life and Work," 103 [1988]: 10-23) offers interesting remarks on the relations between interpretation of biographical data and fiction.

In the effort to correct what he sees as an excessive attachment to the wish for coherence in interpretation, however, Caramagno leans too far in the other direction. For the adult-child model of criticism Caramagno rightly disapproves of, he substitutes a doctor-patient model that silences Woolf's own voice just as effectively.

The known data of her experience, as Woolf recorded them and as others who knew her have corroborated, seem to me largely dismissed by Caramagno as having had no significant influence on the process of her breakdowns. He writes of "the loss of her mother, the sexual abuse inflicted by her half brothers, and so on" (11); that casual "and so on" ignores territory richly explored (and "interpreted") by many readers whose work in his essay is either ignored or treated too reductively (e.g., DeSalvo and Poole).

Caramagno describes Quentin Bell's biography of Woolf as "slanted and sexist" (11) but then draws heavily on it for biographical information and interpretation. For example, he cites Bell's account of how Woolf "thought people were laughing at her" (15) as evidence that she was unable to differentiate between her "subjective world" and what Caramagno calls the "objective" (whatever that is!). In his autobiography, Leonard Woolf records that people did indeed laugh at his wife in the street and whisper about her as she walked by; he was somewhat perplexed by this.

There is a thematic effort in the essay to rescue Leonard Woolf from what many have perceived to be attacks on him by certain critics, most notably Roger Poole in his The Unknown Virginia Woolf. Caramagno approvingly quotes a "penitent" letter Woolf sent to her husband and says that she seemed to have learned "the integrity of objects, their objective solidity" (15). He goes on to draw a parallel between this supposed experience of Woolf's and a common experience (as he sees it) of her fictional characters. James Ramsay, in To the Lighthouse, is cited as an example of a character who learns the difference between subjective and objective (and "loses simultaneously his idealized childhood vision and his self-serving hatred of his father" [15]).
The relevant passage in the novel actually reads:

So that was the Lighthouse, was it?

No, the other was also the Lighthouse. For nothing was simply one thing. The other was the Lighthouse too.

This brief extract seems to me to encapsulate Woolf's effort against the rationality championed by her husband and his Cambridge peers, a rationality that I think is at work in Caramagno's essay, running contrary to his thesis about the meaninglessness and abstraction of moments in Woolf's fiction.

Caramagno refers to Laura Stephen's institutionalization "for a lifelong psychosis" (I wonder what evidence he has interpreted for this "psychosis"), to J. K. Stephen's having gone "mad after a seemingly insignificant head injury in 1886" (an injury Bell suggests was "fatal" and caused by "some projection from a moving train"), to Fitzjames Stephen's having become "mad and died" (the implication, I suppose, being that he died "of" madness), and to none of Julia Stephen's children by Herbert Duckworth having fallen "ill" (13). As Roger Poole pointed out ten years ago, when "madness," "mad," and "ill" are used in this rambling, loose fashion we should be properly suspicious of diagnoses of Virginia Woolf.

It might, finally, be worth quoting from the preface to the largely ignored second edition of Poole's book, as Poole raises there an issue and a name strongly present by their absence in Caramagno's essay:

Foucault contends that "madness" is arbitrarily defined, at any given moment of history, as that which does not fit into, or which actually militates against and questions, the dominant form of "reason." This dominant form of reason has exclusive access to what Foucault later calls the "discourse of power."

(x)

In such a context, while Caramagno's is certainly an interesting contribution to discussion of an important issue, it perpetuates a power relationship that Virginia Woolf's aesthetic practice continuously works against.

\section{MARK HusSeY}

Pace University

Reply:

The doctor-patient model Hussey mentions is a science-literature model that silences, not Woolf's voice, but the voices of psychobiographers who already play doctor without medical knowledge. The territory they 